\title{
Ancylite-(Ce) from quartz-calcite-chlorite veins in phyllite of the Opava Mountains (SW Poland)
}

\author{
Janusz JANECZEK ${ }^{1, *}$, Krzysztof SZOPA ${ }^{1}$ and Monika FABIAŃSKA ${ }^{1}$ \\ 1 University of Silesia, Institute of Earth Sciences, Będzińska 60, 41-200 Sosnowiec, Poland
}

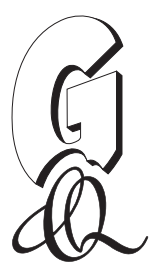

Janeczek, J., Szopa, K., Fabiańska, M., 2020. Ancylite-(Ce) from quartz-calcite-chlorite veins in phyllite of the Opava Mountains (SW Poland). Geological Quarterly, 64 (3): 801-806, doi: 10.7306/gq.1550

Associate Editor: Jacek Szczepański

Ancylite-(Ce) occurs in quartz-calcite-chlorite veins crosscutting the foliation of phyllite in the Dewon Quarry in the foothills of the Opava Mountains of the eastern Sudetes, south-west Poland. Irregularly shaped grains of ancylite are up to $67 \mu \mathrm{m}$ long and $22 \mu \mathrm{m}$ wide. The compositional range of ancylite, determined by electron microprobe, is expressed by the empirical formula: $\quad\left(\mathrm{Sr}_{0.65-0.55} \mathrm{Ca}_{0.19-0.14} \mathrm{Fe}_{0.03-0.00}\right)_{\Sigma 0.87-0.69} \quad\left(\mathrm{Ce}_{0.58-0.50} \mathrm{Nd}_{0.26-0.22} \mathrm{La}_{0.26-0.21} \mathrm{Pr}_{0.06-0.05} \mathrm{Sm}_{0.05-0.04} \mathrm{Gd}_{0.07-0.03} \mathrm{Dy}_{0.01-0.00}\right)_{\Sigma 1.29-1.05}$ $\left(\mathrm{CO}_{3}\right)_{2}\left(\mathrm{OH}_{1.07-0.99} \mathrm{~F}_{0.22-0.0006}\right)_{21.29-1.05} \cdot 0.95-0.93 \mathrm{H}_{2} \mathrm{O}$. Ancylite crystallized directly from $\mathrm{CO}_{2}$-rich hydrothermal solutions as the last mineral in the veins following precipitation of calcite. The solution temperature, estimated using various chlorite geothermometres, was in the range of $260-340^{\circ} \mathrm{C}$.

Key words: ancylite-(Ce), phyllite, $\mathrm{CO}_{2}$-rich hydrothermal solution, Opava Mts., Poland.

INTRODUCTION

Ancylite-(Ce), ideally $\mathrm{CeSr}\left(\mathrm{CO}_{3}\right)_{2}(\mathrm{OH}) . \mathrm{H}_{2} \mathrm{O}$, was once considered a rare accessory mineral of nepheline syenites and carbonatites (Anthony et al., 2003). However, it has recently gained interest as one of the principal rare earth element (REE)-bearing minerals of carbonatites, and as an indicator of hydrothermal or carbothermal processes (Verplanck et al., 2016). On rare occasions, ancylite-(Ce) has been found in rocks other than carbonatites or syenites and their associated pegmatites. For instance, ancylite-(Ce) occurs in the biotite-rich exo-contact of quartz-sulphide veins (Melgarejo et al., 2011) and in granitic pegmatites as a product of hydrothermal alteration of allanite-(Ce) (Novák et al., 2013). Recently, the occurrence of ancylite-(Ce) in quartz-calcite-chlorite veins crosscutting the foliation in the Dewon-Pokrzywna phyllite deposit (DPD), in SW Poland, has been noted, though without details (Sawicka et al., 2018). In this paper, we provide results of electron microprobe analyses (EPMA) of that ancylite-(Ce) and discuss its origin. This is the only occurrence of ancylite-(Ce) in the Sudetes discovered so far.

\footnotetext{
* Corresponding author, e-mail: janusz.janeczek@us.edu.pl Received: May 12, 2020; accepted: June 30, 2020; first published online: August 21, 2020
}

Ancylite-(Ce), together with ancylite-(La) (all collectively termed ancylite if a dominant REE is not specified), and twelve other minerals, belong to the ancylite group of $f$-element carbonates (Godovikov and Nenasheva, 2020) with a general formula:

$$
\left(\mathrm{M}^{2+}\right)_{1+x}(\mathrm{REE})_{3-\mathrm{x}}\left(\mathrm{CO}_{3}\right)_{4}(\mathrm{OH})_{3-x} \cdot(1+\mathrm{x}) \mathrm{H}_{2} \mathrm{O}
$$

where: $\mathrm{M}^{2+}$ are divalent cations $(\mathrm{Ca}, \mathrm{Sr}, \mathrm{Cu}, \mathrm{Pb})$ and $\mathrm{x}$ may vary between -1 and +1 (Larsen and Gault, 2002).

Inspection of ancylite chemical compositions reported in the literature reveals a wide range of $\mathrm{REE}, \mathrm{Sr}$, and $\mathrm{Ca}$ contents and various proportions of individual REE (e.g., Pekov et al., 1997; Yakovenchuk et al., 1997; Bulakh et al., 1998; Zaitsev et al., 1998; Larsen and Gault, 2002; Sadiq et al., 2014; Cooper et al., 2015; Giebel et al., 2017; Ali-Ani et al., 2018; Jia and Liu, 2020). Ancylite with predominantly La (0.54 atoms per formula unit; apfu) and very low $\mathrm{Ce}(0.08 \mathrm{apfu})$, was found in a hydrothermal albitite vein in the llímaussaq alkaline rocks of SW Greenland (Petersen et al., 2001). Analyses of ancylite with $\mathrm{Nd}>\mathrm{Ce}>\mathrm{Pr}>$ La and the minimum $\mathrm{Nd} / \mathrm{Nd}+\mathrm{Ce}$ ratio of 0.456 have been reported from ferro-carbonatites in S Westland, New Zealand (Cooper et al., 2015). Ancylite forms a solid solution with calcio-ancylite-(Ce) and calcio-ancylite-(Nd) (Orlandi et al., 1990; Larsen and Gault, 2002). Such a wide compositional range reflects both the diversity of the local geochemical environments and the flexibility of the ancylite structure to accommodate various proportions of principal and minor elements. 


\section{GEOLOGICAL SETTING}

The ancylite-bearing sample of phyllite was collected in the Dewon Quarry (50.2943942N, 17.4410747E), located in Jarnołtówek, $\sim 5 \mathrm{~km}$ SE of the town of Głuchołazy in the northern foothills of the Opava Mts. in the Eastern Sudetes, SW Poland (Fig. 1). Phyllites intercalated with meta-sandstones and meta-conglomerates belong to the Upper Devonian-Lower Carboniferous Andělská Hora Unit of the Moravo-Silesian foldand-thrust belt (Fig. 1B; Żaba et al., 2005; Żelaźniewicz and Aleksandrowski, 2008). Flysch-type sedimentary deposits, predominantly alternating slates and psammitic slates, were the protolith for the phyllites (Stańczak, 2016). The protolith was metamorphosed under low-temperature greenschist facies to high-temperature sub-greenschist facies conditions (Sawicka
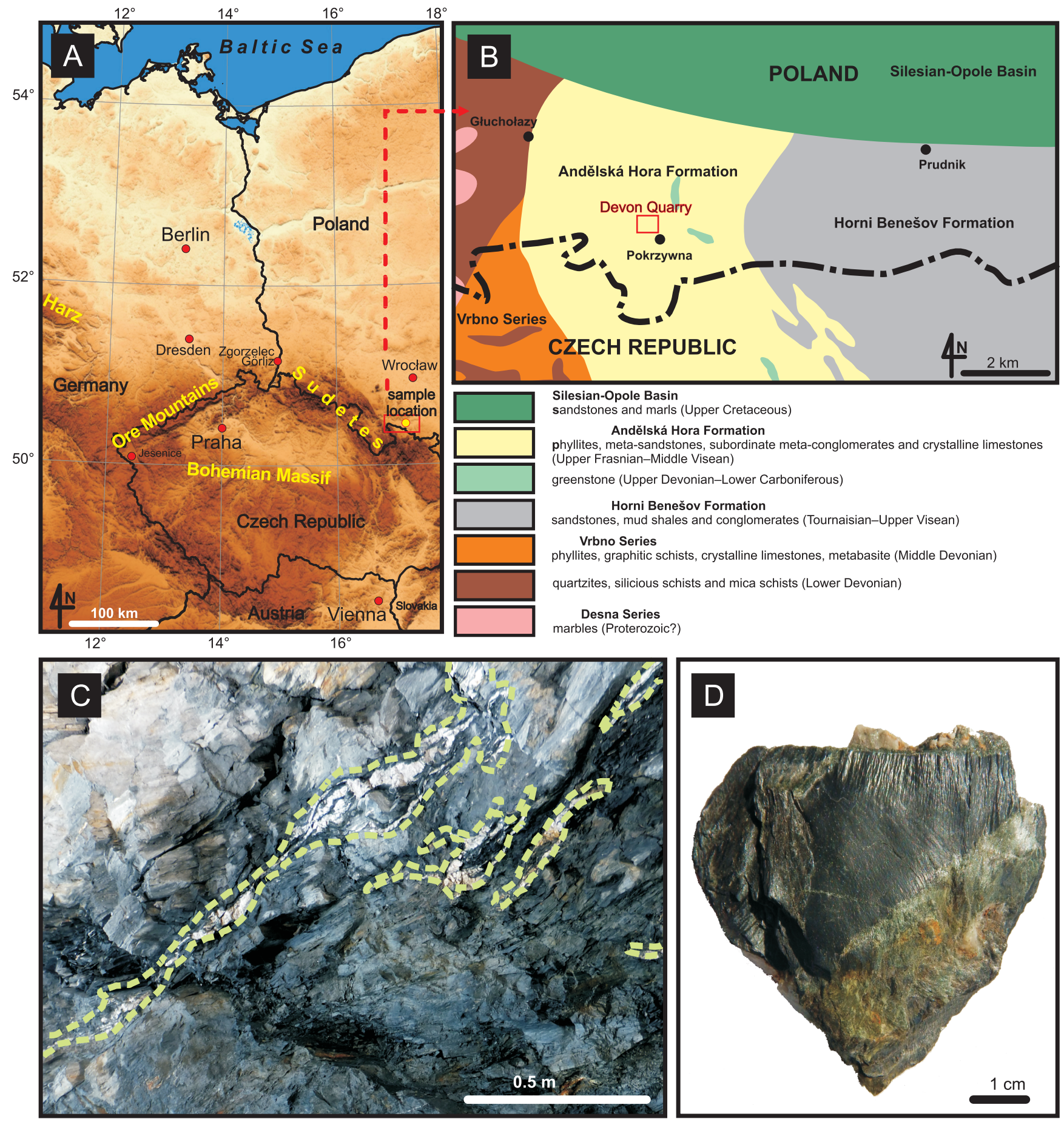

Fig. 1A - location of the sample site in SW Poland; B - simplified geological map of the western margin of the Upper Silesia Block (modified after Żaba et al., 2005) with the location of the Dewon phyllite Quarry; C - quartz- and quartz-calcite-chlorite veins in folded and sheared phyllites in the Dewon Quarry; D - hand specimen of phyllite adjacent to the quartz-calcite-chlorite vein 
et al., 2018). The phyllites were intensely folded and sheared during four major stages of tectonic deformation (Żaba et al., 2005).

Phyllites in the Dewon Quarry are composed of quartz, muscovite, chlorite (Mg-ripidolite), and albite as the principal minerals. Biotite, microcline, illite, and kaolinite are minor constituents. IImenite, apatite, zircon, allanite, monazite, and xenotime are accessory minerals (Sawicka et al., 2018). The argillaceous phyllites are highly enriched in Fe compared to phyllites from other localities worldwide. Their dark grey colour (Fig. 1D) is due to finely dispersed amorphous organic matter originating from bacterial degradation of marine plankton (Sawicka et al., 2018). The phyllites were affected by intense hydrothermal activity as shown by the occurrence of abundant sulphides (pyrite, chalcopyrite and cobaltite) and numerous quartz-calcite, quartz, and quartz-albite veins of various thickness, either intra-foliated or cross-cutting foliation (Fig. 1C).

\section{METHODS}

Observations by scanning electron microscopy (SEM) in the back-scattered electron (BSE) mode were conducted using a Philips XL30 ESEM/TMP scanning electron microscope equipped with an energy-dispersive EDAX type Sapphire spectrometer and BSE detector operated at $15 \mathrm{kV}$. The working distance was $10 \mathrm{~mm}$. The chemical composition of ancylite-(Ce) and associated minerals (i.e., calcite, chlorite, apatite) was determined by wavelength-dispersive spectrometry (WDS) at the Inter-Institutional Laboratory of Microanalyses of Minerals and Synthetic Substances, University of Warsaw, using a CAMECA $S X-100$ electron microprobe operated at an accelerated voltage of $15 \mathrm{kV}$ and a sample current of $10 \mathrm{nA}$. Counting time for peak and background was $4 \mathrm{~s}$. The beam diameter was either 5 or $10 \mu \mathrm{m}$, depending on the grain size. ZAF correction procedure was used for data reduction. Reference materials, analytical lines, diffracting crystals, mean detection limits (in wt.\%) and uncertainties are given in Appendix 1* $^{*}$

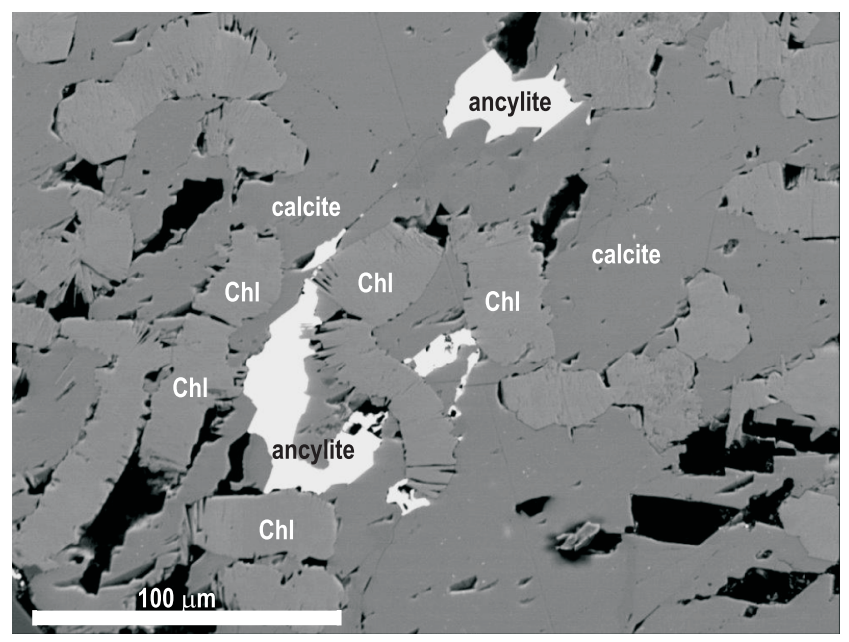

Fig. 2. BSE image of xenomorphic ancylite-(Ce) in the quartz-calcite-chlorite (Chl) vein in phyllite

\section{RESULTS}

Irregularly shaped grains of ancylite-(Ce), up to $67 \mu \mathrm{m}$ long and $22 \mu \mathrm{m}$ wide, occur between calcite and Fe-Mg-chlorite in quartz-calcite-chlorite veins cross-cutting the phyllite foliation (Fig. 2). They appear uniform in BSE images. However, despite the lack of visible zoning, the electron microprobe analyses revealed significant differences in the contents of both major and minor elements within the grains investigated (Appendix 2). The compositional range of the ancylite- $(\mathrm{Ce})$ is expressed by the following empirical formula derived from data in Appendix 2 and calculated based on two cations in the formula unit: $\left(\mathrm{Sr}_{0.65-0.55} \mathrm{Ca}_{0.19-0.14} \mathrm{Fe}_{0.03-0.00}\right)_{\Sigma 0.87-0.69}\left(\mathrm{Ce}_{0.58-0.50} \mathrm{Nd}_{0.26-0.22} \mathrm{La}_{0.26-0.21}\right.$ $\left.\mathrm{Pr}_{0.06-0.05} \mathrm{Sm}_{0.05-0.04} \mathrm{Gd}_{0.07-0.03} \mathrm{Dy}_{0.01-0.00}\right)_{\Sigma 1.29-1.05}\left(\mathrm{CO}_{3}\right)_{2}\left(\mathrm{OH}_{1.07-0.99}\right.$ $\left.\mathrm{F}_{0.22-0.0 .06}\right)_{\Sigma 1.29-1.05} \cdot 0.95-0.93 \mathrm{H}_{2} \mathrm{O}$.

The sum of divalent cations $(\mathrm{Sr}+\mathrm{Ca}+\mathrm{Ba}+\mathrm{Fe})$ is in the 0.704 to 0.857 apfu range (Appendix 2) instead of the ideal 1.000 apfu. According to Dal Negro et al. (1975) there is a random (disordered) distribution of divalent and trivalent (REE) cations in the ancylite structure corresponding to the general formula of $\mathrm{RE}_{\mathrm{x}}(\mathrm{Sr}, \mathrm{Ca})_{2-\mathrm{x}}\left(\mathrm{CO}_{3}\right)_{2}(\mathrm{OH})_{\mathrm{x}} \cdot(2-\mathrm{x}) \mathrm{H}_{2} \mathrm{O}$. Thus, an $\mathrm{Sr}$ deficit is possible in ancylite and the charge balance is maintained by $(\mathrm{OH}+\mathrm{F})$ equal to the sum of REE. Numerous published EPMA data give the sum of $\mathrm{Sr}+\mathrm{Ca}+\mathrm{Ba}+\mathrm{Th}$ as low as 0.502 (e.g., Cooper et al., 2015). The $\mathrm{Sr} /(\mathrm{Sr}+\mathrm{Ca}$ ) ratio in the ancylite-(Ce) examined is in the 0.71 to 0.83 range as a result of very limited Ca substitution for $\mathrm{Sr}$.

Some analyses in Appendix 2 show enrichment in Nd relative to La with an $\mathrm{Nd} /$ La ratio of up to 1.20 (mean 1.03). Cerium is a dominant $\mathrm{REE}$ in all analyses. The $\mathrm{Ce} /(\mathrm{REE}-\mathrm{Ce})$ ratio ranges from 0.45 to 0.47 (Appendix 2). The ancylite-(Ce) investigated, compared to ancylite from other localities, is slightly enriched in $Y+$ HREE, particularly in Gd (Appendix 2). The amount of $\mathrm{REE}+\mathrm{Y}$ decreases in the following order: $\mathrm{Ce}>\mathrm{NdLa}>\mathrm{Pr}>\mathrm{Gd}>\mathrm{Sm}>\mathrm{Y}>\mathrm{Dy}$.

The Sr and REE contents in the ancylite-(Ce) examined are within the range of ancylite chemical compositions from the worldwide localities compiled by Cooper et al. (2015). Compositional datasets of DPD ancylite-(Ce) plot on the $\mathrm{Sr}$ versus REE diagram in the middle, between the extreme ancylite compositions reported in the literature (Fig. 3).

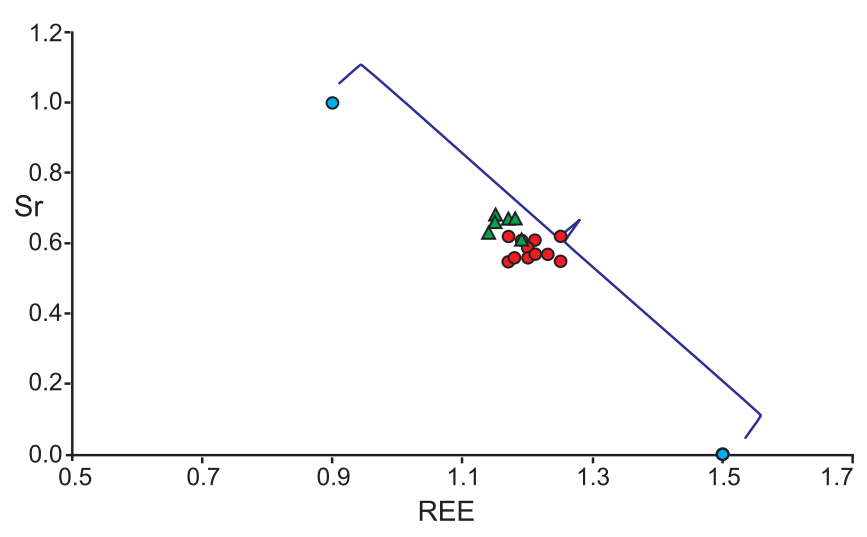

Fig. 3. Sr versus REE plot for the ancylite examined (red dots sample 1; green triangles - sample 2 in Appendix 2) compared to the extreme ancylite-group compositions (blue dots) taken from Cooper et al. (2015)

\footnotetext{
* Supplementary data associated with this article can be found, in the online version, at doi: 10.7306/gq.1550
} 


\section{ORIGIN OF THE ANCYLITE}

The mode of the occurrence of the ancylite suggests its crystallisation directly from the vein-forming $\mathrm{CO}_{2}$-rich hydrothermal solution as the latest mineral (Fig. 2). The temperature of that solution was estimated from the chemical composition of chlorite (intermediate between ripidolite and sheridanite) associated with the ancylite-(Ce) (Appendix 3), using various empirical chlorite geothermometers (Cathelineau and Nieva, 1985; Kranidiotis and MacLean, 1987; Jowett, 1991; Zang and Fyfe, 1995; Rugierri et al., 2006). All of these geothermometers relate the number of tetrahedral $\mathrm{Al}$ ions $\left(\mathrm{Al}^{\mathrm{IV}}\right)$ in chlorite to its crystallisation temperature, because there is a systematic increase in $\mathrm{Al}^{\mathrm{IV}}$ with temperature. The number of $\mathrm{Al}^{\mathrm{IV}}$ in the chlorites examined ranges from 2.25 to 2.69 apfu as calculated on the basis of 28 oxygens (Appendix 3), i.e., within the range observed by Sawicka et al. (2018) in slightly peraluminous chlorites of the ripidolite-sheridanite series from both phyllite matrix and quartz-calcite veins. The average temperatures obtained from the chlorite geothermometers are in the $261-342^{\circ} \mathrm{C}$ range (Fig. 4), i.e., within the temperature range of the phyllite formation (Sawicka et al., 2018).

The ancylite crystallisation apparently took place from a residual solution relatively enriched in $\mathrm{Sr}$ and $\mathrm{REE}$, and depleted in Ca due to earlier crystallisation of calcite. The $\mathrm{SrO}$ content in calcite adjacent to the ancylite ranges from 0.33 to $0.69 \mathrm{wt} . \%$,

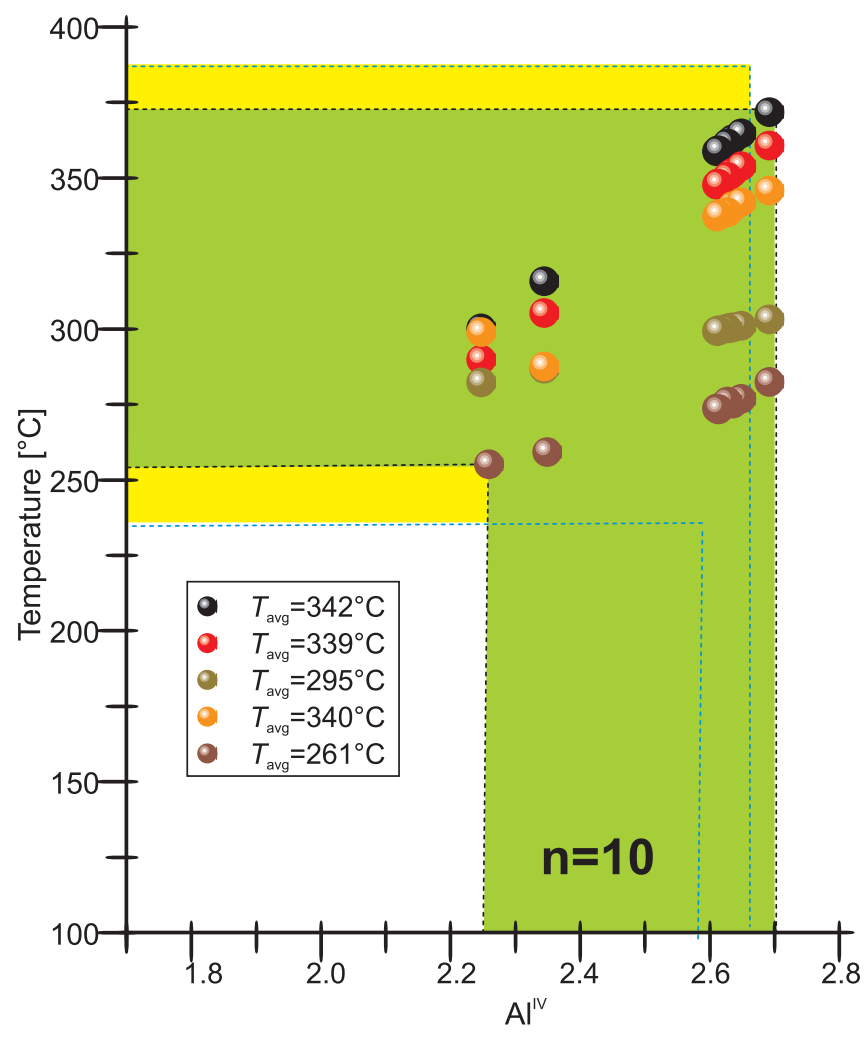

Fig. 4. Tetrahedral Al versus temperature plot for chlorites from the ancylite-bearing quartz-calcite-chlorite vein

Solid circles depict temperature calculated using the chlorite geothermometers of: Cathelineau and Nieva (1985) (black), Kranidiotis and MacLean (1987) (red), Jowett (1991) (orange), Zang and Fyfe (1995) (pale-green), and Rugierri et al. (2006) (pale-brown); yellow field after Sawicka et al. (2018) corresponding to 0.003 and $0.008 \mathrm{Sr}$ per formula unit, respectively (Appendix 4), equivalent to $\sim 0.5 \mathrm{~mol}^{\circ} \mathrm{SrCO}_{3}$. This content of $\mathrm{Sr}$ is small compared to $2.41 \mathrm{~mol}^{2} \mathrm{SrCO}_{3}$ in calcite associated with ancylite from the ferrocarbonatites of south Westland in New Zealand (Cooper et al., 2015). Nevertheless, even small initial concentrations of Sr and REE in the hydrothermal solution were sufficient to precipitate ancylite from the residual solution after the crystallisation of calcite. Strontium and $\mathrm{REE}$ together with $\mathrm{F}$ were concentrated in the residual solution following the calcite crystallisation and reached supersaturation level with respect to ancylite.

There are two possible sources of $\mathrm{Sr}$ and REEs in the quartz-calcite veins: internal and external. Phyllite was originally a fine-grained sedimentary rock such as shale or mudstone, composed mainly of clay minerals as well as detrital minerals and/or authigenic sedimentary phases. Many sedimentary rocks, including shale or mudstone, can host detrital grains as well as authigenic ones, which commonly are carriers for REEs and Y (e.g., Evans and Zalasiewicz, 1996; Alipour-Asll et al., 2012; Szopa et al., 2014, 2020). The protolith of the rock could have included barite, which is widespread in fine-grained clastic sediments, and can be a $\mathrm{Ba}$ and $\mathrm{Sr}$ source (e.g., Stamatakis and Hein, 1993; Fernandes et al. 2017). These elements may have been leached and concentrated by fluids from within the host phyllite, most likely by dissolution of $\mathrm{Sr}$ - and REE-bearing accessory detrital minerals, namely fluorapatite, allanite, monazite, and xenotime. Like ancylite-(Ce), these minerals are light REE-rich and Ce-dominant as revealed by their EDS spectra, with the exception of xenotime, which may have been a source for $Y$ and HREE. Fluorapatite is the second most abundant accessory detrital mineral, after ilmenite, in the phyllite. Its rounded grains are up to $60 \mu \mathrm{m}$ in diameter and are evenly dispersed throughout the phyllite matrix. The SrO and REE oxide contents in the fluorapatite are on $\sim 0.14$ and 0.46 wt. $\%$, respectively, equivalent to $0.014 \mathrm{Sr}$ apfu and 0.029 REE apfu (Appendix 5). While Ce is dominant among REE in the fluorapatite, an enrichment in $\mathrm{Nd}$ is noticeable with a $\mathrm{Nd} / \mathrm{La}$ ratio of 2.25 , even higher than observed in the ancylite-(Ce) (Appendix 2). The whole-rock contents of $\mathrm{Sr}$ and $\mathrm{Y}$ in the phyllite examined are 79 and $22 \mathrm{ppm}$, respectively, as determined by XRF during this study (Winiarski, 2019 unpubl. data).

In this respect, the gold-bearing quartz carbonate veins in phyllite of the Middle Devonian Vrbno Series - a tectono-metamorphic unit adjoining the Andělská Hora Formation to the west (Fig. 1B), formed during the late phase of the Variscan orogeny (Foit et al., 2012). The tectonic deformation of the phyllite and intra-foliated quartz veins in the Dewon Quarry took place within the same timeframe (Żaba et al., 2005).

A composite, post-orogenic Žulova pluton composed of biotite granite ( $291 \pm 5 \mathrm{Ma})$, granodiorite, and quartz monzodiorite (292 \pm 4 Ma; Laurent et al., 2014) is a possible external source of REE in hydrothermal fluids that may have circulated within the phyllites of the Andělská Hora Formation after the Variscan orogeny. The main body of the Žulova Pluton occurs $\sim 15 \mathrm{~km}$ west of the Dewon Quarry. However, there are numerous small granite outcrops outside the pluton. One of them occurs in Gierałcice $\sim 10 \mathrm{~km}$ north-west of the Dewon Quarry. Pegmatite dykes within the Gierałcice granite are enriched in $Y+R E E$ up to $512 \mathrm{ppm}$, whereas quartz veins have much lower contents of these elements in the 7 to $49.5 \mathrm{ppm}$ range (Lasoń and Markowiak, 2019).

Clearly, a definitive statement about the source of $\mathrm{Sr}$ and REE requires significantly more investigation, which is outside the scope and intent of the present study. 


\section{CONCLUSIONS}

Data obtained in this study support the results of previous investigators that showed a wide compositional range in ancylite, particularly for REE, Sr/REE, and $\mathrm{Sr} / \mathrm{Ca}$. While ancylite-(Ce) from the Dewon Quarry is slightly enriched in Y + HREE compared to ancylite from other localities, its composition is in the middle of the compositional range for this mineral reported in the literature.

The ancylite-(Ce) crystallisation within the quartz-calcite-chlorite veins was possible due to a relative increase in concentrations of essential elements (Sr, REE and F) in the residual solution following calcite crystallisation. An open question remains whether the microscopic quantities of ancylite-(Ce) reported in this paper reflect its incidental occurrence in the phyllite or whether it is a more widespread mineral in the abundant quartz-calcite veins cross-cutting the phyllites throughout the Andělská Hora Formation.

Acknowledgements. The final version of this paper benefited greatly from critical reviews and suggestions by Al. F. Cooper and an anonymous reviewer. We thank Prof. P. Kennan and A. Gumsley for their help in improving the English of the manuscript. This study was financially supported by the Polish National Science Center (NCN) grant to M. Fabiańska: 2014/15/B/ST10/02281.

\section{REFERENCES}

Al-Ani, T., Molnár, F., Lintinen, P., Leinonen, S., 2018. Geology and mineralogy of rare earth elements deposits and occurrences in Finland. Minerals, 8: 356.

Alipour-AsII, M., Mirnejad, H., Milodowski, A.E., 2012. Occurrence and paragenesis of diagenetic monazite in the upper Triassic black shales of the Marvast region, South Yazd, Iran. Mineralogy and Petrology, 104: 197-210.

Anthony, J.W., Bideaux, R.A., Bladth, K.W., Nichols, M.C., 2003. Handbook of Mineralogy, Volume V. Borates, Carbonates, Sulfates. Mineral Data Publishing, Tucson, Arizona.

Bulakh, A.G., Le Bas, M.J., Wall, F., Zaitsev, A.N., 1998. Ancylite-bearing carbonatites of the Seblyavr massif, Kola peninsula, Russia. Neues Jahrbuch für Mineralogie Monatshefte, (4): 171-192.

Cathelineau, M., Nieva, D., 1985. A chlorite solid solution geothermometer. The Los Azufres (Mexico) geothermal system. Contributions to Mineralogy and Petrology, 91: 235-244.

Cooper, A.F., Collins, A.K., Palin, J.M., Spratt, J., 2015. Mineralogical evolution and REE mobility during crystallisation of ancylite-bearing ferrocarbonatite, Haast River, New Zealand. Lithos, 216-217: 324-337.

Dal Negro, A., Rossi, G., Tazzoli, V., 1975. The crystal structure of ancylite, $\quad(\mathrm{REE})_{x}(\mathrm{Ca}, \mathrm{Sr})_{2-x}\left(\mathrm{CO}_{3}\right)_{2}(\mathrm{OH})_{\times} \cdot(2-\mathrm{x}) \mathrm{H}_{2} \mathrm{O}$. American Mineralogist, 60: 280-284.

Evans, J., Zalasiewicz, J., 1996. U-Pb, $\mathrm{Pb}-\mathrm{Pb}$ and $\mathrm{Sm}-\mathrm{Nd}$ dating of authigenic monazite: implications for the diagenetic evolution of the Welsh Basin. Earth and Planetary Science Letters, 144: 421-433.

Fernandes, N.A., Gleeson, S.A., Magnall, J.M., Creaser, R.A., Martel, E., Fischer, B.J., Sharp, R., 2017. The origin of Late Devonian (Frasnian) stratiform and stratabound mudstone-hosted barite in the Selwyn Basin, Northwest Territories, Canada. Marine and Petroleum Geology, 85: 1-15.

Foit, B., Dolníček, Z., Nepejchal, M., 2012. Gold in the quartz veins of the Hláska and Vysoká hora, north field of the Andělská Hora Ore District, Jeseníky Mts., Czech Republic (in Czech with English summary). Acta Musei Moraviae - Scientiae Geologicae, 97: 47-67.

Giebel, R.J., Gauert, C.D.K., Marks, M.A.W., Costin, G., Markl, G., 2017. Multi-stage formation of REE minerals in the Palabora Carbonatite Complex, South Africa. American Mineralogist, 102: $1218-1233$

Godovikov, A.A., Nenasheva, S.N., 2020. Structural-chemical systematics of minerals. Springer Nature Switzerland AG.

Jia, Y., Liu, Y., 2020. REE enrichment during magmatic-hydrothermal processes in carbonatite - related REE deposits: a case study of the Weishan REE deposit, China. Minerals, 10: 25.
Jowett, E., 1991. Fitting iron and magnesium into the hydrothermal chlorite geothermometer. Proceedings of the GAC/MAC/SEG Joint Annual Meeting, Toronto, ON, Canada, 27-29 May 1991, 16: A62.

Ketcham, R.A., 2015. Technical note: calculation of stoichiometry from EMP data for apatite and other phases with mixing on monovalent anion sites. American Mineralogist, 100: $1620-1623$.

Kranidiotis, P., MacLean, W.H., 1987. Systematics of chlorite alteration at the Phelps Dodge massive sulfide deposit, Matagami, Quebec. Economic Geology, 82: 1898-1911.

Larsen, A.O., Gault, R.A., 2002. Calcio-ancylite-(Ce) from syenite pegmatite at Tvedalen, Oslo Region, Norway. Neues Jahrbuch für Mineralogie Monatshefte, 9: 411-423.

Lasoń, K., Markowiak, M., 2019. Rare Earth Elements in selected rocks of the Strzelin-Głuchołazy area (Eastern Sudetes) (in Polish with English summary). Biuletyn Państwowego Instytutu Geologicznego, 477: 55-68.

Laurent, A., Janoušek, V., Magna, T., Schulmann, K., Míková, J., 2014. Petrogenesis and geochronology of a post-orogenic calc-alkaline magmatic association: the Žulová Pluton, Bohemian Massif. Journal of Geosciences, 59: 415-440.

Melgarejo, J.C., Abat, L.T., Tárrega, E.A., Crego, M.C., DeWitt, M.C.J., Kgothang, L.P., Fernández, J.A.P., Bruchs, J.M., Lewis, J.F., 2011. Sulfide deposits associated with $\mathrm{Cl}$ metasomatism along thrusts in black shales, Tsodilo, Botswana. Macla Revista de la Sociedad Española de Mineralogía, 15: 129-130.

Novák, M., Kadlec, T., Gadas, P., 2013. Geological position, mineral assemblages and contamination of granitic pegmatites in the Moldanubian Zone, Czech Republic; examples from the Vlastějovice region. Journal of Geosciences, 58: 21-47.

Orlandi, P., Pasero, M., Vezzalani, G., 1990. Calcio-ancylite-(Nd), a new REE-carbonate from Baveno, Italy. European Journal of Mineralogy, 2: 413-418.

Pekov, I.V., Petersen, O.V., Voloshin, A.V., 1997. Calcioancylite-(Ce) from llímaussaq and Narssârssuk, Greenland, Kola peninsula and Polar Urals, Russia; ancylite-(Ce) calcio-ancylite-(Ce) an isomorphous series. Neues Jahrbuch für Mineralogie Abhandlungen, 171: 309-322.

Petersen, O.V., Niedermayr, G., Gault, R.A., Brandstätter, F., Micheelsen, H.I., Giester, G., 2001. Ancylite-(La) from the llímaussaq alkaline complex, South Greenland: contribution to the mineralogy of Ilímaussaq. Neues Jahrbuch für Mineralogie Monatshefte, 106: 493-504.

Rugierri, G., Petrone, C.M., Gianelli, G., Arias, H., Henriquez, E.T., 2006. Hydrothermal alteration in the Berlin geothermal field 
(El Salvador): new data and discussion on the natural state of the system. Periodico di Mineralogia, 75: 293-312.

Sadiq, M., Rantjith, A., Umrao, R.K., 2014. REE mineralization in the carbonatites of the Sung Valley ultramafic-alkalinecarbonatite complex, Meghalaya, India. Central European Journal of Geosciences, 6: 457-475.

Sawicka, N., Janeczek, J., Fabiańska, M., Bahranowski, K., Krzykawski, T., Matuszewska, A., 2018. Mineralogy and organic geochemistry of phyllite from the Dewon-Pokrzywna deposit, the Opava Mountains (SW Poland). Geological Quarterly, 62 (4): 817-828.

Stamatakis, M.G., Hein, J.R., 1993. Origin of barite in Tertiary marine sedimentary rocks from Lefkas Island, Greece. Economic Geology, 88: 91-103.

Stańczak, G., 2016. Slates, phyllites and schists from deposits of SW Poland used as dimension stones - evaluation of their decorativeness and the possibilities of use (in Polish with English summary). Przegląd Geologiczny, 64: 833-843.

Szopa, K., Skreczko, S., Chew, D., Krzykawski, T., Szymczyk, A., 2020. Multi-Tool (LA-ICPMS, EMPA and XRD) investigation on heavy minerals from selected Holocene peat-bog deposits from the Upper Vistula River Valley, Poland. Minerals, 10: doi.org/10.3390/min10010009.

Szopa, K., Brachaniec, T., Krzykawski, T., 2014. Preliminary EMPA and XRD investigation on detrital minerals from the Štramberk Limestone in the Czech Republic. Neues Jahrbuch für Geologie und Paläontologie Abhandlungen, 276: 201-212.
Verplanck, P.L., Mariano, A.N., Mariano, A. Jr., 2016. Rare earth element ore geology of carbonatites. Reviews in Economic Geology, 18: 5-32.

Zaitsev, A.N., Wall, F., Le Bas, M.J., 1998. REE-Sr-Ba minerals from the Khibina carbonatites, Kola Peninsula, Russia: their mineralogy, paragenesis and evolution. Mineralogical Magazine, 62: 225-250.

Zang, W., Fyfe, W.S., 1995. Chloritization of the hydrothermally altered bedrock at the Igarape-Bahia gold deposit, Carajas, Brazil. Mineralium Deposita, 30: 30-38.

Żaba, J., Ciesielczuk, J., Malik, K., Strzyżewska-Konieczna, S., 2005. Budowa oraz ewolucja strukturalna utworów dewońsko-karbońskich Gór Opawskich (strefa morawsko-ślaska) (in Polish). In: Geologia i zagadnienia ochrony środowiska w regionie górnośląskim (eds. J. Jureczka, Z. Buła and J. Żaba): 116-127. LXXVI Zjazd naukowy Polskiego Towarzystwa Geologicznego, Rudy k/Rybnika, 14-16 września 2005. Państwowy Instytut Geologiczny, Polskie Towarzystwo Geologiczne, Warszawa.

Żelaźniewicz, A., Aleksandrowski, P., 2008. Tectonic subdivision of Poland: southwestern Poland (in Polish with English summary). Przegląd Geologiczny 56: 904-911.

Yakovenchuk, V.N., Menshikov, Yu.P., Pakhomovsky, Ya.A., Ivanyuk, G.Yu., 1997. Ancylite-(La) $\mathrm{Sr}(\mathrm{La}, \mathrm{Ce})\left(\mathrm{CO}_{3}\right)_{2}(\mathrm{OH}) \cdot \mathrm{H}_{2} \mathrm{O}$ - A new carbonate from hydrothermal vein at the Kukisvumchorr Mountain (Khibiny Massif) and its comparison with ancylite-(Ce) (in Russian). Zapiski Vserossiyskogo Mineralogicheskogo Obshchestva, 126: 96-108. 